\title{
Coconut Shell Applications For Making Antenna Tv In Madrasah Aliyah Muhammadiyah 09 Kwala Madu
}

\author{
Minto Supeno ${ }^{1 *}$, Mimpin Ginting ${ }^{1}$ \\ ${ }^{1}$ Departement of Chemistry,Faculty of Mathematic And Science Universitas Sumatera Utara, \\ Medan, Indonesia \\ *Email: minto@usu.ac.id
}

\begin{abstract}
Shell antenna is an original UHF antenna technology, produced from research continuous and observations for years. Natural polymeric material from a combination soft-hard that can be relied upon as a television antenna at a radius of $180 \mathrm{~km}$, with antenna gain $11 \mathrm{~dB}$, which can be used in the lowlands, highlands and at the bottom of the sea. This antenna is very good performance for high frequencies. The UHF shell antenna prototype consists of: (1) Two rectifiers the first wave from the shell pores and the second from the smooth almonium plate that is mounted lined up inside the shell parts; (2) reflector of almonium; and (3) carbonyl groups and micro elements as a receiver. The advantages of this antenna can close up more clear, clear, cool clearer eyes and reception, can be used in the lowlands, highlands and at the bottom sea, this antenna is very good performance for high frequencies, can close up clearer, clear, cool in the eyes and voice reception clearer.
\end{abstract}

Keywords: Shell antenna, UHF antenna, polymer material

\begin{abstract}
Abstrak
Antena batok merupakan teknologi antena UHF yang original, dihasilkan dari penelitian bersinambung serta pengamatan selama bertahun-tahun. Material polimer alam dari kombinasi soft-hard yang dapat diandalkan sebagai antena televisi pada radius $180 \mathrm{~km}$, dengan gain antenna $11 \mathrm{~dB}$, yang dapat digunakan di dataran rendah , tinggi dan didasar laut. Antena ini sangat baik kinerja untuk frequensi tinggi. Protipe antena batok UHF terdiri dari : (1) Dua buah penyearah gelombang pertama dari pori-pori batok dan kedua dari plat halus almonium yang dipasang berderet dibagian dalam belahan batok; (2) reflektor dari almonium; dan (3) gugus karbonil dan unsur mikro sebagai receiver. Keunggulan antena ini dapat close up lebih jelas, bening, sejuk dimata dan penerimaan suara lebih jelas, dapat digunakan di dataran rendah, tinggi dan di dasar laut, antena ini sangat baik kinerja untuk frequensi tinggi, dapat close up lebih jelas, bening, sejuk dimata dan penerimaan suara lebih jelas.
\end{abstract}

Kata kunci : Antena batok, antenna UHF, material polimer

\section{PENDAHULUAN}

Antena outdoor yang beredar di pasaran mempunyai kelemahan pada penerimaan gambar close up kurang jelas dan tajam, kondisi demikian perlu diperbaiki dan hal demikian karena antenna mempunyai penyearah dimana jarak antar elemen aluminium sangat jauh, sehingga menghasilkan gambar yang kurang jelas. Perbaikan dilakukan dengan memanfaatkanL limbah tempurung kelapa dimana tempurung mempunyai pori-pori yang berfungsi sebagai penyearah dengan jarak antar pori mikro meter.Sehingga menghasilkan gambar yang sangat jelas pada waktu close up. Apabila kelapa digoncang-goncang maka akan terdengar riak air kelapa ke telinga,fakta demikian menunjukkan bahwa tempurung kelapa mempunyai celah atau pori-pori.pori-pori ini yang membawa gelombang air kelapa ketelinga,yang keluar melalui antar muka lignin selulosa.Gejala awal demikian mengartikan bahwa tempurung kelapa dapat memantulkan dan menyerap gelombang (Supeno, 2007). 
Hasil penelitian komposisi tempurung kelapa tua terdiri dari air $(\mathbf{8 , 3 \%}), \mathbf{a b u}$ $(0,6 \%)$,lignin $(29,6 \%)$,selulosa $(26,6 \%)$,pentosan $(27,7 \%)$, uronat anhidrat $(3,5 \%)$ dan zat ekstraktif $(\mathbf{4 , 2 \%})$. Berdasarkan komposisi diatas maka tempurung kelapa didominasi oleh lignin,selulosa dan pentosa.Struktur tempurung kelapa mempunyai cincin benzene,maka kekerasan pada tempurung kelapa tua meningkat pada tempurung kelapa terdapat daerah antar muka lignin selulosa.Yang dapat dipandang 2 buah plate sejajar yang berbeda potensialnya,atau antar muka terjadi pertemuan kedua potensial yang berotasi.Jika diberikan gelombang elektromagnetik molekul polimer akan bervibrasi dan berotasi.Jika medan listrik konstan diberikan pada sample,tingkat energy bergeser sejauh yang ditentukan oleh besaran momen dipol molekul,pemisahan keadaan oleh medan listrik (efek stark) (Supeno, 2007).

\section{METODE PELAKSANAAN}

\subsection{Alat Percobaan}

Panci aluminium, plat penjepit tiang, tempat tiang antenna, pipa aluminium, reflector, ring, baut, mur, kabel

\subsection{Bahan Percobaan}

Bahan dasar pembuatan antenna TV ini adalah batok kelapa.

\subsection{Prosedur Percobaan}

Kelapa tua yang telah dipecah dua dan dibersihkan dari daging buah maupun sabutnya selanjutnya digosok mengggunakan gerenda atau kertas gosok.Tempurung demikian direndam dengan menggunakan $\mathrm{NaOH}$ (1-5) $\mathrm{M}$ selama (1-3) hari pada suhu $30-40^{\circ} \mathrm{C}$. Perendaman ini berguna untuk memperbesar pori-pori batok kelapa selanjutnya tempurung kelapa direbus pada aquadest mendidih selama (1-24) jam guna menurunkan lignin sampai $(20-23,5) \%$.Tempurung kelapa dikeringkan pada terik matahari sehingga kadar air mencapai 0,01-2\% selama (1-5) hari.Tempurung kelapa yang ada matanya (bagian atas) dilubangi menggunakan bor untuk tempat baut dan mur yang berjarak 1-2 cm.Dimana baut ini tempat penghubung kapasitor $210 \mathrm{pF}$ dan resistor $470 \mathrm{Ohm}$. Sedangkan bagia belahan tengah diberikan lempengan aluminium berjajar dan dilekatkan dengan lem kayu.Antena tempurung kelapa ini sangat baik bekerja pada ferekuensi 400-1000 Mhz dan dapat diatas $1000 \mathrm{MHz}$,dengan Gain antenna berada pada kisaran 9,08-11,2 dB.Sehingga antenna ini baik untuk ultra high frequensi (UHF) dan radius penerimaan mencapai $180 \mathrm{Km}$ yang diukur menggunakan metode baring.

\section{HASIL DAN PEMBAHASAN}

Hasil penelitian komposisi tempurung kelapa tua terdiri dari air $(\mathbf{8 , 3 \%})$,abu $(\mathbf{0 , 6 \%})$,lignin $(29,6 \%)$,selulosa $(26,6 \%)$,pentosan $(27,7 \%)$,uronat anhidrat $(3,5 \%)$ dan zat ekstraktif $\mathbf{( 4 , 2 \% ) . B e r d a s a r k a n ~ k o m p o s i s i ~ d i a t a s ~ m a k a ~ t e m p u r u n g ~ k e l a p a ~ d i d o m i n a s i ~ o l e h ~}$ lignin,selulosa dan pentosa.Struktur tempurung kelapa mempunyai cincin benzene,maka kekerasan pada tempurung kelapa tua meningkat pada tempurung kelapa terdapat daerah antar muka lignin selulosa.Yang dapat dipandang 2 buah plate sejajar yang berbeda potensialnya,atau antar muka terjadi pertemuan kedua potensial yang berotasi.Jika diberikan gelombang elektromagnetik molekul polimer akan bervibrasi dan berotasi.Jika medan listrik konstan diberikan pada sample,tingkat energy bergeser sejauh yang ditentukan oleh besaran momen dipol molekul,pemisahan keadaan oleh medan listrik (efek 
Minto Supeno et.al. Coconut Shell Applications For Making Antenna Tv In Madrasah Aliyah Muhammadiyah 09 Kwala Madu

stark).lignin selulosa mempunyai karbonil (C-O) yang spesies isotope dengan spectrum rotasi murni seperti table 1 . untuk transisi rotasi murni ${ }_{12} \mathrm{C} 16 \mathrm{O}$ pada $\mathrm{v}=0$, yaitu :

Tabel 1.Level Transisi rotasi murni C-O

\begin{tabular}{|l|l|l|l|l|l|}
\hline $\mathrm{J} \rightarrow \mathrm{J}+1$ & $0 \rightarrow 1$ & $1 \rightarrow 2$ & $2 \rightarrow 3$ & $3 \rightarrow 4$ & $4 \rightarrow 5$ \\
\hline $\mathrm{v} / \mathrm{MHz}$ & 115,271 & 230,538 & 345,796 & 461,041 & 576,268 \\
\hline
\end{tabular}

Batok kelapa didalam merupakan polimer hard atau very hard, karena komposisi lignin > sellulosa, material demikian tidak baik sebagai antena TV. Karena jika diberi gelombang elektromagnetik akan terjadi vibrasi molekul >> rotasi murni. Untuk mengatasi ini maka konsentrasi lignin diturunkan sehingga konsentrasi lignin < sellulosa maka dapat digunakan sebagai antena TV, HP, karena material demikian telah menjadi material soft. Kombinasi polimer soft > hard ini secara teori dapat digunakan untuk keperluan mendeteksi gempa bumi, satelit dll.

\section{KESIMPULAN}

Antena batok merupakan teknologi antena UHF yang original,dihasilkan dari penelitian bersinambung serta pengamatan selama bertahun-tahun. Material polimer alam dari kombinasi soft-hard yang dapat diandalkan sebagai antena televisi pada radius 180 $\mathrm{km}$,dengan gain antena $11 \mathrm{~dB}$, yang dapat digunakan di dataran rendah, tinggi dan didasar laut.Antena ini sangat baik kinerja untuk frekuensi tinggi.

\section{UCAPAN TERIMAKASIH}

Penulis mengucapkan terima kasih kepada LPPM USU melalui dana Non PNBP Universitas Sumatera Utara sesuai dengan Surat Perjanjian Penugasan Pelaksanaan Pengabdian Kepada Masyarakat Program IBKIK Tahun Anggaran 2017 Nomor : 3223/UN5.2.3.2.1/PPM/2017, Tanggal 24 Juli 2017.

\section{DAFTAR PUSTAKA (REFERENCES)}

Attar N, Korkmaz Y. Effect of two light-emitting diode (LED) and one halogen curing light on the microleakage of class V flowable composite restorations. J Contemporary Dent Pract 2007; 8(2) : 1-10.

Supeno, 2007. Bentonit Alam Terpilar Sebagai Material Katalis/Co-Katalis Pembuatan Gas Hidrogen Dan Oksigen Dari Air. Medan. Universitas Sumatera Utara

Supeno, M.., and Siburian, R. 2018. New route: Convertion of coconut shell tobe graphite and graphene nano sheets. Journal of King Saud University - Science. Article in Press.

Supeno, 2003. Analisis Hambatan Karbon Dalam Lingkungan Asam-Basa. Medan. Universitas Sumatera Utara 